\title{
DEPRESI PADA IBU-IBU YANG MEMPUNYAI ANAK CACAT YANG BERSEKOLAH DI YAYASAN PEMBINAAN ANAK CACAT (YPAC) MANADO
}

\author{
${ }^{1}$ Herdy Munayang \\ ${ }^{1}$ Lisbeth F. J. Kandou \\ ${ }^{2}$ Novie Rampengan \\ ${ }^{1}$ Melisa E. Sumarauw \\ ${ }^{1}$ Bagian Psikiatri Fakultas Kedokteran Universitas Sam Ratulangi Manado \\ ${ }^{2}$ Bagian Ilmu Kesehatan Anak Fakultas Kedokteran Universitas Sam Ratulangi Manado \\ Email: munayangherdy@yahoo.com
}

\begin{abstract}
According to data from the WHO, depression is still a serious public health problem. Depression is a disorder of human function related to feelings of sadness and its accompanying symptoms including alterations of sleep, appetite, psychomotor, concentration, anhedonia, and fatigue patterns. This study aimed to obtain degrees of depression by using the Hamilton Depression Rating Scale (HDRS) among mothers of disabled children who were studying at the Center for Disabled Children (YPAC) Manado. This was a descriptive study with a cross sectional design. There were 35 samples meeting the inclusion criteria. The results showed that by using the HDRS there were seven respondents (20\%) showing normal personality and 28 respondents (80\%) suffering from depression, mostly between the ages of 29-45 years (62.85\%). From samples suffering from depression, there were 20 respondents (71.4\%) with mild depression, seven (25\%) with moderate depression, and one with severe depression (3.6\%). Conclusion: A high number of mothers, especially at the ages of 29-45 years, of disabled children who were studying at YPAC Manado showed several degrees of depression. Among the depressed mothers, most suffered from mild depression.
\end{abstract}

Keywords: mother, depression, disabled children, Hamilton Depression Rating Scale (HDRS)

\begin{abstract}
Abstrak: Menurut data WHO, depresi masih merupakan masalah kesehatan dunia yang serius. Depresi adalah terganggunya fungsi manusia yang berkaitan dengan alam perasaan sedih dan gejala penyertanya, termasuk perubahan pola tidur, nafsu makan, psikomotor, konsentrasi, anhedonia, dan kelelahan. Penelitian ini bertujuan untuk mendapatkan angka kejadian dan tingkat depresi dengan menggunakan Hamilton Depression Rating Scale (HDRS) pada para ibu yang memiliki anak cacat yang bersekolah di Yayasan Pembinaan Anak Cacat (YPAC) Manado. Penelitian ini bersifat deskriptif dengan menggunakan metode potong lintang. Sampel yang memenuhi kriteria inklusi berjumlah 35 orang. Hasil penelitian memperlihatkan bahwa dengan menggunakan Hamilton Depression Rating Scale (HDRS) terdapat tujuh responden berkepribadian normal dan 28 responden dengan depresi berbagai tingkat, terutama pada usia 29-45 tahun. Depresi ringan ditemukan sebesar 71,4\%, depresi sedang 25\%, dan depresi berat 3,6\%. Simpulan: Sebagian besar ibu yang memiliki anak cacat yang bersekolah di YPAC Manado mengalami depresi, terutama depresi ringan.
\end{abstract}

Kata kunci: ibu, depresi, anak cacat, Hamilton Depression Rating Scale (HDRS).

Depresi merupakan salah satu masalah kesehatan mental utama saat ini, yang mendapat perhatian serius di negara berkem- bang. WHO memrediksikan bahwa pada tahun 2020 depresi akan menjadi salah satu penyakit mental yang banyak diidap setelah 
serangan jantung. Depresi merupakan suatu masa terganggunya fungsi manusia yang berkaitan dengan alam perasaan sedih dan gejala penyertanya, termasuk perubahan pola tidur dan nafsu makan, psikomotor, konsentrasi, anhedonia, kelelahan, rasa putus asa dan tidak berdaya, serta bunuh diri. $^{1-3}$

Kejadian depresi dua kali lebih sering mengenai perempuan dibandingkan lakilaki di berbagai belahan dunia. Hasil survei Perhimpunan Dokter Spesialis Kedokteran Jiwa di Indonesia pada Juni 2007 mengemukakan bahwa sekitar 94\% masyarakat Indonesia mengidap depresi, mulai tingkat ringan sampai berat. ${ }^{4-5}$ Data dari Badan Pusat Statistik Nasional tahun 2007 mengemukakan bahwa terdapat 82.840.600 jiwa anak dari 231.294.200 jiwa penduduk Indonesia, dimana sekitar 8,3\%, juta jiwa di antaranya merupakan anak berkebutuhan khusus. Anak berkebutuhan khusus adalah seorang anak yang karena kejadian atau kecelakaan tertentu mengalami penyimpangan dan hambatan dalam perkembangan alat indra, fisik, mental, maupun sosial, yang dapat berlanjut dalam keterbatasan kemampuannya untuk memenuhi kebutuhan gerak sehari-hari.

Seorang anak yang cacat memerlukan bantuan orang lain lebih dari anak normal untuk memenuhi kebutuhan dasarnya, baik kebutuhan fisik, sosial, atau pendidikannya. Keluarga memegang peranan penting terutama ibu untuk membantu kebutuhan dasar, fisik, sosial, dan pendidikan anak sehari-hari. $^{6-7}$ Menurut Lazarus dan Folkman, model dari stress dan coping dalam keluarga mengatakan orang tua yang mempunyai anak-anak cacat menunjukkan berbagai masalah psikososial termasuk depresi, kecemasan, dan perilaku marah karena menghadapi berbagai kesulitan yang parah dalam merawat kebutuhan anak-anak mereka serta adanya perasaan pesimis tentang masa depan anak. ${ }^{8}$

\section{EPIDEMIOLOGI}

Gangguan depresi berat merupakan suatu gangguan yang sering ditemukan, dengan prevalensi seumur hidup sekitar $15 \%$, dan $25 \%$ sering terjadi pada perempuan. Rata-rata usia onset untuk gangguan depresi kira-kira 40 tahun; 50\% kasus mempunyai onset antara usia 20-50 tahun. $^{9}$

\section{PENYEBAB DEPRESI}

Beberapa bukti dari studi pencitraan berteknologi tinggi menunjukkan bahwa individu yang depresi memiliki perubahan fisik di dalam otak. Pentingnya perubahan ini masih belum pasti, namun setidaknya dapat membantu menentukan penyebab.

Beberapa penelitian menunjukkan bahwa depresi lebih sering terjadi pada orang yang anggota keluarganya memiliki kondisi tersebut. Beberapa peneliti berupaya untuk menemukan gen yang mungkin terlibat dalam menyebabkan depresi. Penyebab faktor lingkungan juga perllu mendapat perhatian, antara lain akibat adanya situasi dalam hidup yang sulit untuk diatasi seperti kehilangan orang yang dicintai dan masalah keuangan. Selain itu, individu dengan kepribadian tertentu seperti anti sosial, mudah cemas dan lebih bergantung pada orang lain mempunyai risiko lebih besar menjadi depresi. ${ }^{10-11}$

\section{PSIKOPATOLOGI DEPRESI}

Depresi pada umumnya dicetuskan oleh peristiwa hidup tertentu seperti kehilangan orang yang dicintai, masalah keuangan, atau memiliki anak berkebutuhan khusus. Individu yang terkena depresi pada umumnya menunjukkan gejala psikis, fisik, dan sosial. Individu yang mengalami depresi cenderung memandang segala sesuatu dari sisi negatif, termasuk menilai diri sendiri. $^{12}$

\section{TAHAP-TAHAP MEMAHAMI DAN PENERIMAAN ANAK CACAT}

Dalam tahap penyangkalan, orang tua menolak untuk sepenuhnya menerima apa yang terjadi pada mereka yang memiliki anak berkebutuhan khusus. Mereka merasa 
dunianya terguncang dan kehilangan anak sehat yang mereka impikan. Kemudian terdapat tahap kegelisahan atau kecemasan dimana orang tua merasa cemas karena ketidak-pastian masa depan anaknya serta merasa malu terhadap penilaian masyarakat tentang anak mereka yang cacat. Bila hal ini berlangsung terus, maka muncul rasa bersalah. Kebanyakan orang tua menyalahkan diri sendiri. Orang tua memandang kejadian tersebut sebagai suatu hukuman. Umumnya depresi terjadi ketika orang tua mengalami kesedihan yang mendalam, merasa diri tidak berguna, dan tidak mempunyai harapan tentang masa depan anaknya. Pada tahap pengakuan dan penerimaan, seiring berjalannya waktu orang tua mulai beradaptasi dengan keadaan, serta mengakui dan menerima keber-adaan anaknya yang cacat. ${ }^{7}$

\section{GEJALA DEPRESI}

Gejala depresi adalah kumpulan perilaku dan perasaan yang secara spesifik dapat dikelompokkan sebagai depresi. Gejala depresi ini bisa dilihat dalam tiga aspek, yaitu keluhan somatik, gangguan psikomotor dan psikologis. ${ }^{12}$

\section{DIAGNOSIS DEPRESI BERDASAR- KAN PPDGJ III}

Berdasarkan Pedoman Penggolongan Diagnosis Gangguan Jiwa Edisi ke-3 (PPDGJ III), diagnosis depresi digolongkan atas: F32 Episode depresif; F32.0 Episode depresif ringan; F32.1 Episode depresif sedang; F32.2. Episode depresif berat tanpa gejala psikotik; dan F32.3 Episode depresif berat dengan gejala psikotik. ${ }^{13}$

\section{Klasifikasi depresi menurut DSM-IV (Diagnostic and Statistical Manual of Mental Disorders fourth edition) ${ }^{10}$}

\section{Kriteria untuk gangguan depresi berat ${ }^{10}$}

1. Didapatkan lima (atau lebih) gejala depresi selama dua minggu. Kriteria tersebut ialah:

a. Mood terdepresi hampir sepanjang hari, hampir setiap hari seperti yang ditunjukkan oleh laporan subjektif (misalnya:merasa sedih) atau pengamatan yang dilakukan oleh orang lain (misalnya:tampak sedih).

b. Hilangnya minat atau kesenangan secara jelas dalam hampir semua/ semua aktivitas sepanjang hari.

c. Penurunan berat makan yang bermakna jika tidak melakukan diet atau penambahan berat badan (misalnya: perubahan berat badan lebih dari 5\% dalam satu bulan), atau peningkatan nafsu makan setiap hari.

d. Insomnia hampir setiap hari.

e. Agitasi atau retardasi psikomotor hampir setiap hari.

f. Kelelahan atau hilangnya energi hampir setiap hari.

g. Perasaan tidak berharga atau rasa bersalah yang berlebihan.

h. Hilangnya kemampuan untuk memusatkan perhatian hampir setiap hari.

i. Pikiran akan kematian/ide bunuh diri

2. Gejala tidak memenuhi kriteria untuk episode campuran

3. Gejala yang menyebabkan penderitaan yang bermakna secara klinis atau gangguan dalam fungsi sosial, pekerjaan, atau fungsi penting lain.

4. Gejala bukan karena efek fisiologis langsung dari suatu zat (misalnya: obat yang disalahgunakan) atau suatu kondisi medis umum (misalnya: hipotiroidisme)

5. Gejala tidak lebih baik diterangkan oleh dukacita, yaitu, setelah kehilangan orang yang dicintai, gejala menetap lebih dari dua bulan atau ditandai oleh gangguan fungsional yang jelas, rasa tidak berharga.

\section{PENANGANAN}

Penatalaksanaan pasien harus diarahkan kepada beberapa tujuan.1) Farmakoterapi: sebagian besar klinisi memilih salah satu obat trisiklik, atau Selective serotonin re-uptake inhibitors (SSRI), atau penghambat Mono-Amin-Oksidase (MAO) sebagai obat lini pertama dalam pengobatan gang- 
guan depresi. 2) Psikoterapi: terapi keluarga, Cognitive Behavior Therapy (CBT), Terapi interpersonal (IPT). ${ }^{14-15}$

\section{PENGUKURAN DEPRESI}

Hamilton depression rating scale (HDRS) ialah tes yang mengukur keberatan dari gejala depresi pada individu. Nilai tingkat depresi: 1) $<7$ tidak ada depresi; 2) 7-17 depresi ringan; 3) 18-24 depresi sedang; dan 4) $>24$ depresi berat. ${ }^{16}$

\section{PENGERTIAN ANAK, ANAK CACAT, JENIS-JENIS ANAK CACAT}

Anak menurut undang-undang adalah seseorang yang belum berumur 18 (delapan belas) tahun termasuk anak yang masih dalam kandungan. Anak cacat menurut pasal 1 Undang-Undang No 4 tahun 1997 yaitu anak yang pertumbuhan dan perkembangannya mengalami penyimpangan baik segi fisik mental dan emosi serta sosialnya bila dibandingkan dengan anak lain yang sebaya sehingga menimbulkan hambatan tingkah laku sikap dalam menyesuaikan diri dengan lingkungannya. Jenisjenis anak cacat: tuna rungu, kehilangan pendengaran yang akan mengakibatkan gangguan pada komunikasi dan bahasa; tuna grahita, intelegensi dibawah intelegensi anak normal; dan tuna daksa, gangguan fisik yang berkaitan dengan tulang, otot, sendi, dan sistem persarafan. ${ }^{17-21}$

\section{METODE PENELITIAN}

Jenis penelitian yang dipakai ialah deskriptif dengan menggunakan desain cross-sectional yang dilakukan di Yayasan Pembinaan Anak Cacat (YPAC) Manado selama bulan Desember 2011-Januari 2012. Sampel penelitian yaitu ibu-ibu yang anaknya bersekolah di YPAC Manado dan bersedia. Variabel yang dinilai dikelompokkan berdasarkan usia, pekerjaan, pendidikan, status pernikahan dan jenis kecacatan anaknya. Instrumen penelitian menggunakan kuesioner HDRS.

\section{Pengumpulan data}

Responden diminta mengisi lembar persetujuan lalu dilakukan wawancara langsung mengenai identitas dan gejalagejala depresi berdasarkan HDRS yang terdiri dari 24 butir pertanyaan. Setiap pertanyaan diberikan angka 0-3 atau 4, kemudian dianalisis dan hasilnya disajikan dalam bentuk tabel.

\section{HASIL PENELITIAN}

Penelitian dilakukan terhadap depresi pada ibu-ibu yang memiliki anak cacat yang bersekolah di YPAC Manado mulai bulan Desember 2011 sampai dengan bulan Januari 2012. Jumlah responden yang diperoleh 35 orang ibu.

Dari 35 orang responden, didapatkan yang tidak depresi tujuh orang (20\%) dan yang depresi 28 orang (80\%), terdiri dari: depresi ringan 20 orang (71,4\%), depresi sedang tujuh orang (25\%), dan depresi berat satu orang $(3,6 \%)$.

Berdasarkan usia responden, didapatkan depresi usia 29-45 tahun sebanyak 28 orang dan usia 46-63 tahun sebanyak tujuh orang (Tabel 1).

Tabel 1. Distribusi berdasarkan usia

\begin{tabular}{cccccc}
\hline \multirow{2}{*}{ Usia } & \multirow{2}{*}{$\mathbf{N}$} & \multicolumn{2}{c}{ Tidak depresi } & \multicolumn{2}{c}{ Depresi } \\
& & $\mathbf{N}$ & $\mathbf{\%}$ & $\mathbf{N}$ & $\mathbf{\%}$ \\
\hline $29-45$ & 28 & 6 & 17,14 & 22 & $\mathbf{6 2 , 8 5}$ \\
$46-63$ & 7 & 1 & 2,85 & 6 & 17,14 \\
\hline Total & 35 & 7 & 20 & 28 & 80 \\
\hline
\end{tabular}

Berdasarkan pekerjaan responden didapatkan yang mengalami depresi terbanyak ialah Ibu Rumah Tangga (IRT), yaitu sebanyak 62,85\% (Tabel 2).

Tabel 2. Distribusi responden berdasarkan pekerjaan

\begin{tabular}{cccccc}
\hline \multirow{2}{*}{ Pekerjaan } & \multirow{2}{*}{ N } & \multicolumn{2}{c}{ Tidak Depresi } & \multicolumn{2}{c}{ Depresi } \\
& & $\mathbf{N}$ & $\mathbf{\%}$ & $\mathbf{N}$ & $\mathbf{\%}$ \\
\hline IRT & 28 & 6 & 17,14 & 22 & 62,85 \\
Wiraswasta & 7 & 1 & 2,9 & 6 & 17,14 \\
\hline Total & 35 & 7 & 20 & 28 & 80 \\
\hline
\end{tabular}


Berdasarkan pendidikan responden didapatkan yang mengalami depresi terbanyak mempunyai pendidikan SLTA, yaitu sebanyak 45,71\% (Tabel 3).

Tabel 3. Distribusi berdasarkan pendidikan.

\begin{tabular}{cccccc}
\hline \multirow{2}{*}{ Pendidikan } & \multirow{2}{*}{ N } & \multicolumn{2}{c}{ Tidak Depresi } & \multicolumn{2}{c}{ Depresi } \\
& & N & \% & N & \% \\
\hline SLTP & 11 & 1 & 2,86 & 10 & 28,57 \\
SLTA & 22 & 6 & 17,14 & 16 & $\mathbf{4 5 , 7 1}$ \\
Sarjana & 2 & 0 & 0 & 2 & 5,8 \\
\hline Total & 35 & 7 & 20 & 28 & 80 \\
\hline
\end{tabular}

Berdasarkan status pernikahan responden didapatkan yang mengalami depresi terbanyak ialah ibu-ibu yang sudah menikah, yaitu sebanyak 80\% (Tabel 4).

Tabel 4. Distribusi berdasarkan status pernikahan.

\begin{tabular}{cccccc}
\hline \multirow{2}{*}{$\begin{array}{c}\text { Status } \\
\text { pernikahan }\end{array}$} & N & \multicolumn{2}{c}{$\begin{array}{c}\text { Tidak } \\
\text { depresi }\end{array}$} & \multicolumn{2}{c}{ Depresi } \\
& & $\mathbf{N}$ & $\mathbf{\%}$ & $\mathbf{N}$ & $\mathbf{\%}$ \\
\hline Menikah & 35 & 7 & 20 & 28 & $\mathbf{8 0}$ \\
Belum & & & & & \\
menikah & 0 & 0 & 0 & 0 & 0 \\
Cerai & 0 & 0 & 0 & 0 & 0 \\
\hline Total & 35 & 7 & 20 & 28 & 80 \\
\hline
\end{tabular}

Berdasarkan jenis kecacatan anak dari responden yang mengalami depresi didapatkan yang terbanyak pada ibu-ibu yang memiliki anak tuna grahita, yaitu sebanyak 42,6\% (Tabel 5).

Tabel 5. Distribusi berdasarkan jenis kecacatan anak pada ibu-ibu yang memiliki anak cacat.

\begin{tabular}{cccccc}
\hline \multirow{2}{*}{$\begin{array}{c}\text { Jenis } \\
\text { Kecacatan }\end{array}$} & N & \multicolumn{2}{c}{$\begin{array}{c}\text { Tidak } \\
\text { Depresi }\end{array}$} & \multicolumn{2}{c}{ Depresi } \\
& & N & \% & N & \% \\
\hline Tuna rungu & 15 & 5 & 14,2 & 10 & 28,6 \\
Tuna grahita & 17 & 2 & 5,8 & 15 & $\mathbf{4 2 , 6}$ \\
Tuna daksa & 2 & 0 & 0 & 3 & 8,6 \\
\hline Total & 35 & 7 & 20 & 28 & 80 \\
\hline
\end{tabular}

\section{BAHASAN}

Tingginya angka depresi berhubungan dengan faktor risiko seperti kepribadian tertutup dan adanya stresor sosial, misalnya percekcokan yang berlangsung hampir setiap hari dalam rumah tangga karena memiliki anak berkebutuhan khusus serta merasa dituduh menyebabkan terjadi kecacatan pada anaknya. ${ }^{22-23}$

Menurut Levinson, usia 20-45 tahun merupakan masa peralihan dari masa remaja ke dewasa awal, yang merupakan masa untuk membentuk kehidupan yang lebih tetap dan stabil dan masa penyesuaian diri dimana seseorang mulai mengatur hidup dan bertanggung jawab dengan kehidupannya, seperti membangun rumah tangga, memulai karir/pekerjaan, serta mewujudkan impian-impian yang ada semasa remaja. $^{23}$ Pada penelitian ini ditemukan $62,85 \%$ responden yang mengalami depresi berusia 29-45 tahun; hal ini sesuai dengan yang dikemukakan oleh Levinson yaitu bahwa kelompok usia ini merupakan masa peralihan.

Depresi lebih banyak terjadi pada wanita yang sudah menikah dibandingkan wanita lajang. Hal ini disebabkan karena wanita yang sudah menikah memiliki banyak tugas seperti menjadi istri, ibu, dan harus mengurus kehidupan rumah tangganya. ${ }^{12}$ Pada penelitian ini, berdasarkan status pernikahan jumlah responden yang mengalami depresi terbanyak yang sudah menikah.

Pada penelitian yang dilakukan terhadap IRT di Yogyakarta didapatkan IRT mudah mengalami depresi karena banyaknya masalah yang harus dialami dalam kehidupan rumah-tangganya terutama yang berhubungan dengan perilaku suami dan mengurus kebutuhan anakanak. ${ }^{24-25}$ Pada penelitian ini didapatkan jumlah responden yang mengalami depresi terbanyak ialah IRT; hal ini sesuai dengan yang dikemukakan oleh Monks dan Haditono, ${ }^{24}$ serta Safitri. $^{25}$

Berdasarkan jenis kecacatan anaknya, jumlah responden yang mengalami depresi lebih banyak pada ibu-ibu yang memiliki 
anak tuna grahita. Hal ini mungkin disebabkan karena jumlah responden yang memiliki anak tuna grahita merupakan jumlah terbesar dari keseluruhan responden, yaitu 17 dari 35 responden.

\section{SIMPULAN}

Dari hasil penelitian disimpulkan bahwa sebagian besar ibu-ibu yang memiliki anak cacat yang bersekolah di YPAC Manado mengalami depresi, terutama yang bentuk ringan, dan terbanyak pada usia 2945 tahun, status menikah, dan pekerjaan sebagai ibu rumah tangga (IRT).

\section{SARAN}

Diperlukan adanya sarana untuk memperoleh bantuan, pengobatan, dan konseling, serta melakukan pendekatan secara psikologis antara lain memberikan motivasi untuk meningkatkan kualitas hidup dari ibu-ibu yang memilki anak cacat yang bersekolah di YPAC Manado.

YPAC memberikan layanan bantuan berupa pembelajaran dan terapi yang memadai di sekolah untuk anak-anak cacat agar dapat membantu meminimalisasikan kecacatan pada anak dan menjadikan anak mandiri yang dapat membantu menghindari ibu-ibu dari depresi.

\section{DAFTAR PUSTAKA}

1. World Health Orgnization .Depression [homepage on the Internet]. Nodate [cited 2011 Nov 16]. Available from: URL:http://www.who.int/mental_health /management/depression/definition/en/.

2. Lubis NL. Depresi Tinjauan Psikologis. Jakarta: Kencana Prenada Media Group, 2009.

3. Puri BK. Pocket Essential of Psychiatry (Third Edition). Philadelpia: Saunders Elseiver, 2010.

4. Wade C, Tavris C. Depresi. In: Hardani MW, editor. Psikologi Jilid 2. Jakarta: Erlangga, 2007; p.337.

5. Sutarto. 94 persen masyarakat mengalami depresi [homepage on the Internet]. Nodate [cited 2011 Nov 6]. Available from:
URL:http://www.tempo.co.id/hg/nasion al/2007/06/20/brk,20070620102281,id.html

6. Kementerian Kesehatan Republik Indonesia. Pedoman Umum Perlindungan Kesehatan anak berkebutuhan khusus, 2010; p. 1-2

7. Kesulitan Psikososial Orang tua dengan anak-anak penyandang catat berat [homepage on the Internet]. Nodate [cited 2011 Nov 6]. Available from: URL:http://www.parenting-journals. com/84/prominent-psychosocialdifficulties-that-parents-of-youngchildren-with-severe-disabilities-maycope-with-during-theirchild\%E2\%80\%99s-early-years/

8. Sutatminingsih R, Maulina B. Stress ditinjau dari harga diri pada Ibu yang memiliki anak penyandang retardasi mental.. Psikologia. 2005;1(1):9-18.

9. Kaplan HL, Sadock BJ. Sinopsis Psikiatri Jilid I. Tangerang: Bina Rupa Aksara, 2010; p.804.

10. Mayo Foundation for Medical Education and Research. Major depression. [homepage on the Internet]. 2008 [updated 2011 Feb 10; cited 2011 Nov 6]. Available from: http://www.mayo clinic.com/health/depression/DS00175

11. Amir N. Aspek Neurobiologi Molekuler Depresi: Depresi Aspek Neurobiologi Diagnosis dan Tatalaksana. Jakarta: Balai Penerbit Fakultas Kedokteran Universitas Indonesia, 2005; p.25.

12. Lumbantobing SM. Depresi: Neurogeriatri. Jakarta: Balai penerbit Fakultas Kedokteran Universitas Indonesia, 2010. p.158-9.

13. Maslim R. Diagnosis Gangguan Jiwa. Jakarta: Penerbit Bagian Ilmu Kedokteran Jiwa FK Unika Atmajaya, 2001; p.64-5.

14. Siste K, Ismail IR. Buku Ajar Psikiatri. Jakarta: Balai Penerbit Fakultas Kedokteran Indonesia, 2010; p.209-22.

15. Hamilton Depression Scale - children, paranoia, adults, examples, person, people, used, medication, score [homepage on the Internet]. Nodate [Cited 2011 November 6]. Available from: URL: http://www.minddisorders. com/Flu-Inv/Hamilton-DepressionScale.html

16. Gunawan SG, Elysabeth. Psikotropik: 
Farmakologi dan Terapi (Edisi Kelima). Jakarta: Balai Penerbit FKUI, 2008; p.161.

17. Definisi anak menurut undang-undang [homepage on the Internet]. Nodate [cited 2011 Nov 16]. Available from: URL:http://id.shvoong.com/socialsciences/sociology/2170479pengertian-anak/\#ixzz1dgNqmmrN

18. Hardiyanti EA. Anak. Indikator Perbaikan Kesehatan Lingkungan Anak. Jakarta: Buku Kedokteran EGC, 2009; p.2.

19. Supriyono HAW. Psikologi Anak Luar Biasa: Psikologi Belajar. Jakarta: Rineka Cipta, 2004; p.52.

20. Anak Berkebutuhan Khusus [homepage on the Internet]. Nodate [cited 2011 Nov 15]. URL:http://staff.uny.ac.id/sites/ default/files/ABK\%20TUK\%20TENDI K.pdf
21. Smart A, Rose. Anak Cacat Bukan Kiamat (Metode Pembelajaran \& Terapi untuk Anak Berkebutuhan Khusus). Yogyakarta: Katahati, 2010; p.49.

22. Arijanto W. Derajat depresi dan faktorfaktor yang mempengaruhi-nya pada orang tua anak berkebutuhan khusus di komunitas Percik Insani. Sosiohumoniora. 2008 Juli: 38-7.

23. Gerkensmeyer JE, Perkins SM. Matternal Depressive Symptoms When Caring for a Child with Men-tal Problems. J Child Fam Stud. 201;685-95.

24. Monks FJ, Haditono SR. Psikologi Perkembangan. Yogyakarta: Gadjah Mada University Press, 2006; p.326.

25. Safitri. Hubungan antara kekerasan dalam rumah tangga dengan depresi pada ibu rumah tangga [Skripsi]. Jakarta: Universitas Islam Indonesia; 2009: 56-6. 